\title{
Investigation of Relationship Between Managerial Triple Skills and Staff's Performance of Red Crescent in Fars Province
}

\author{
Zare Sadabadi Narjes* and Hosseini Seyed Heydar \\ Department of Business Management, Payame Noor University, \\ P O BOX 19395-3697 Tehran, I. R. of Iran
}

DOI: http://dx.doi.org/10.13005/bbra/1933

(Received: 12 September 2015; accepted: 07 November 2015)

\begin{abstract}
Today, managers should adopt various roles for success in performing of their duties and specific skills are needed to perform them. The need to inform these skills enough in managerial positions is the main challenges facing with managers. Given the importance of management performance and its effect on staffs' performance, the present study was performed based on investigation of relationships between triplet managerial skills and staff's performance of Red Crescent in Fars Province. This study was a survey research and had been implemented in field. The statistical communities of the research were included 167 managers and 360 staffs on three levels of high, middle and operational and they were randomly selected using stratified random sampling method. The statistical samples based on Morgan table and sampling ratio were 116 managers and 186 employees. The number of 120 managers and 186 staffs were select to ensure more results. Reliability was calculated by SPSS Software. Then, the obtained results were analyzed by Pearson correlation analysis. The results showed that the assumptions of this study (there is a direct and significant correlation between triplet managerial skills and staff's performance of Red Crescent organization in Fars Province) were confirmed using Pearson correlation analysis at level of $\mathbf{9 5} \%$. Considering the above, as managers have more skills (human, conceptual and technical) as a result, better performance of staffs will observe. So skill is considered as an integral part of management.
\end{abstract}

Keywords: Triplet Managerial Skills, staff's performance, Red Crescent, Fars

Large organizations, which are responsible for dealing with some of the most important areas of people's life, have been gradually appeared with development of public and private organizations and Red Crescent organization is among them; managers of these organizations must have an appropriate level of knowledge and understanding, in order to be able to apply their management properly and efficiently. That's why asset owners of these organizations tend to manage the affairs of their organizations to professional managers and to attract cooperation of capable and talented individuals for their management or to act for training and

\footnotetext{
* To whom all correspondence should be addressed. Tel :+989337219366;

E-mail: roja_wersha@yahoo.com
}

guidance of talented and qualified individuals for future management of the organization ${ }^{1}$.

Unlike the classic theory that believes in inherent characteristics for effective leadership, most recently is emphasized on quality of leadership. Namely successful leadership is depended on good behavior, skills and leather performance, not to his personal characteristics ${ }^{2}$. Management skill is said to skills by which a person in own provides possibility of mobilizing in components of a set for proportional movement of all components toward considered goals ${ }^{3}$. So, application of skills is required for all managerial jobs.

Skills are included distinctive traits, personal qualities and talents that you have with yourself and can be transferred to various places. 
Life, education, adaptation and even career need skills. By learning of vocabulary of skills, you can recognize hundreds of skills that exist in your fist. Skills are generally divided into three categories: functional, work-content, and adaptive skills. All of them can be considered "transferable".

Functional skills such as progress according to plan, collecting of data, identifying of problems and responding to them are those that may be associated with a particular job or not. These are called practical skills, since they are employed to perform general duties of a job.

Work-content skills are specific and are limited to a particular profession; for example, librarianship, paper correcting and grading, and ECG interpretation are done by librarians, teachers, and specialist physicians, respectively.

Adaptive or self-management skills are special traits or personal characteristics; the ability to learn fast, the ability to pay to exact details, deontology, self-determination, consistency, sense of cooperation and spiritual joy are some examples of adaptive skills ${ }^{4}$.

Managers must have some management skills to be successful in implementation of their tasks and directorial role. Also, a way to investigate managers' work is paying attention to skills or competencies that they need to achieve for receiving to their goals. Three skills are considered by Robert Katz necessary for management: technical, human and conceptual skills ${ }^{5}$.

Technical skills: technical skills mean the ability to use knowledge or special skills ${ }^{6}$. In other words, obtained ability from experience, education and training in use of knowledge, methods, techniques, and required equipments to do special skills are called technical skills ${ }^{7}$. When you think about skills of professionals such as engineers or surgeons, you are really focused on technical skills ${ }^{6}$.

Acquired skills of accountants, programmers, typists and toolmakers, engineers and machinists are examples of technical skills which determine job performance of individuals at executive level. However, as staffs promote to higher level, their technical skills find relatively less important. These people gradually lean to technical skills of their subordinates and in many cases may never use those skills that supervised on them (2).
Human skills: the ability to work along with understanding and motivation of others individually or in group is called human skills. Most of people are technically skillful but there is no ability of communications between them.

They may not be a good listener, not understand the others requirements or have difficulty in managing of conflicts. When managers do their duties by others, they should have human skills for communication, motivation and delegation ${ }^{6}$.

Perceptual skills: these skills include the ability to think in terms of models, frameworks and widespread relations (such as long-term programs) which have more importance at higher organizational levels. Cognitive skills deal with ideas, while human and technical skills deal with people and objects, respectively. Analysis of management skills helps to explain this fact that why prominent chiefs of departments are sometimes poor assistants for supreme head of their organizations. Since those individuals may not have suitable composition of required skills for higher levels jobs and may particularly not have cognitive skills².

Triplet managerial skills were studied in this research as independent variables. The following indicators are investigable for triplet managerial skills:

\section{Indicators of Managers' Technical Skills}

The first indicator: financial skills- these include skills in which a person implements his turnover and asset as regulated and targeted. A person who finds financial skills in his existence can regulate income and expenditure of a company, an office, or a factory. Financial skills give complete discipline to incomes and expenditures and lateral subjects $^{8}$.

Technical control is a control of a process through which operations are matched with planned activities. This process is employed for continues correction of organization performance to achieve organizational goals and shows the amount of progress toward achieving the goals ${ }^{1}$.

The third indicator- legal skills: to define your rights, you should know your rights first of all and then learn the quality of their actions. In any conflict, human can use powerful dialogue method in addition to war or escape. It all depends on who could speak decisively. Familiarity to 
special rights is not enough alone, and for this purpose familiarity with some of language skills is necessary ${ }^{9}$.

\section{Indicators of Human Skills in Managers}

The first indicator: motivation of staffsmotivation is any effect that enhances reinforcement, orientations, and emergence behaviors ${ }^{10}$.

Motivation of staffs to perform administrative duties and coordination of their goals with organizational goals has particular importance ${ }^{11}$. Every manager has responsibility to help staffs to do their works with efficiency and effectiveness. However, if a manager does not know what will motivate his staffs, can not affect on them and his help will not work ${ }^{10}$.

The second indicator: human control- for the purpose that a manager can be able to play well his important and major role and to strengthen the ability to work with others and to do his work through them. He requires familiarity with methods, techniques and patterns to guide and control him in recognition of past behavior and prediction of future behavior to help behavioral change of those who work with him. What proposed for all managers, supervisors and other people is "the reason of others' behaviors" ${ }^{12}$.

The purpose of human control skills is skill that managers apply to obtain certainty of compatibility "behavior and performance of staffs" with "standards, programs, and organizational goals". In fact, process control compares "ought" and "existent" and measures the distance between current situation and desired status. It can be found through process control whether forecasts of planners have been correct or not ${ }^{1}$.

The third indicator: communication- is a process that planning, organizing, directing and monitoring duties of management is done by it. Also, communication is an activity that managers used it to fulfill coordinating and better using of time $^{13}$.

Managers should establish a clear communication between organizational goals and staffs to motivate them with this communication and to trust to their leadership and to perform their duties in the best way. Managers should effectively communicate with staffs for desirable supervision to pursuit job progress, emphasis on organizational goals and correction of organizational processes ${ }^{14}$.

Coordination- coordination of the above activities is required for success of organization in achieving its goals. In fact, the risk of delay and waste time in activities, projects, and programs increases without coordination and the organization may be faced with frustration and failure. By creation of some dependencies, managers can coordinate efforts of staffs to achieve to desired results ${ }^{1}$.

\section{Indicators of Cognitive Skills of Managers}

The first indicator: strategic thinkingstrategic thinking is a process that explains thinking, evaluating, observing and creating of future by individuals for themselves and others. Strategic thinking is a very effective tool and valuable.

The second indicator: creative thinkingcreative thinking skill provides ability to discover and produce new ideas for us. This kind of skill helps person in the face of disaster to know how to transform negative emotions into positive.

The third indicator: decision makingdecision making is considered as fundamental pillars of all duties and managerial activities. Since every manager is faced with problems in planning, organizing, directing and supervising of duties, one needs to decide. Decision making is selection of one way through different ways and in fact, is selection of the best way to achieve to goals (15).

Decision-making skill according to its realistic goals and with information and sufficient knowledge helps us to select the best solution among various solutions and to apply them and accept its consequences too.

The fourth indicator: problem solvingevery day we are faced with many problems, some are simple and some are complex. Problem solving skill gives us the ability that according to practical experiences and mental capabilities to be able to solve problem and to achieve desired result.

\section{Importance of Evaluating of Performance}

Performance is defined by some experts as the end point of efforts and activities in a period of time, and it is generally a function of individual and environmental factor ${ }^{13}$. Nowadays, evaluation of human force performance is considered as one of important activities of human resource management. And some information is provided through it that emphasize on many of management 
decisions. The performance of staffs and organization improves by proper implementation. Despite many emphasis in this regard, the evaluation of performance has not been established yet in Iran and authorities do not believe in much importance for it ${ }^{16}$.

Evaluation and performance measuring is a systematic effort to understand that to what extent public services meet people's need and to what extent governments can compliance it ${ }^{17}$.

It also states that, suitable and effective performance of staffs is one of successful keys of organization. Good performance means efficiency, quality, profitability, and costumer orientation. That is why successful organizations in the world make great efforts to identify and mange staffs performance and to achieve success and increase their staffs performance (both in terms of amount and quality) by providing these factors.

It has been observed in Red Crescent organization and similar organizations that inadequate skills of managers in different levels of various parts of organization particularly operational managers can bring huge losses on staffs' performance and method of servicing to people. And since the activities of this organization are in direct contact to human life, in this study we want to investigate the relationships between managerial triplet skills (conceptual, human, technical) and staffs' performance in Red Crescent organization in Fars Province.

\section{METHOD}

This study is a survey research and statistical samples according to Morgan Table and sampling ratio were 116 managers and 186 staffs. The number of 120 managers and 186 staffs were select to ensure more of the results. Sampling methods in this study for both community of managers and staffs were stratified random sampling method.

Two questionnaires of managerial triplet skills and staffs' performance each with 22 questions were used to obtain information. Validity of questionnaires was determined by formal validity. So that, both questionnaires were distributed among a number of experts and professors including supervisors and counselor. They were asked to express their opinion about questionnaires which unanimously approved both questionnaires with minor correction. Reliability of the questionnaires in this study was obtained using Cronbach's alpha coefficient and SPSS software for managerial triplet skills 0.84 with 19 samples and for staffs' performance 0.78 with 19 samples. After collecting and extraction of raw data, Pearson correlation was used for analysis.

\section{RESULTS}

\section{The main hypothesis}

$\mathrm{H}_{1}$ : there is a significant correlation between managerial triplet skills and staffs' performance in Red Crescent organization of Fars Performance.

$\mathrm{H}_{0}$ : there is no significant correlation between managerial triplet skills and staffs' performance in Red Crescent organization of Fars Performance.

Pearson correlation coefficient was used in this study to test the research hypothesis based on correlation between managerial triplet skills and staffs' performance. As can be seen in Table 11-4, the correlation coefficient between managerial triplet skills and staffs' performance is 0.493 at significance level of $5 \%$. So with $95 \%$ of certainty can claim that there is a significant correlation between managerial triplet skills and staffs' performance.

The regression coefficient between managerial triplet skills and staffs' performance was 0.726 and its determination coefficient was 0.528 . So variable of managerial triplet skills has ability to explain $52.8 \%$ of variable changes of staffs' performance and/or in other word, the regression line just indicates $52.8 \%$ of changes in staffs' performance.

\section{The first hypothesis}

$\mathrm{H}_{1}$ : there is a direct and significant correlation between managerial triplet skills and staffs' performance in Red Crescent organization of Fars province.

$\mathrm{H}_{0}$ : there is no direct and significant correlation between managerial triplet skills and staffs' performance in Red Crescent organization of Fars province.

Pearson correlation coefficient was used in the present study to test the research hypothesis based on correlation between managers' cognitive 
Table 1. Correlation between managerial triplet skills and staffs’ performance

\begin{tabular}{lcc}
\hline Investigated variables & Correlation coefficient & Significant level \\
\hline Triplet skills of managers and staffs' performance & 0.493 & $0.026^{*}$ \\
\hline
\end{tabular}

Table 2. Regression coefficient of managerial triplet skills and staffs’ performance variables

\begin{tabular}{ccccc}
\hline Model & $\mathrm{R}$ & R Square & Adjusted R Square & Std. Error of the Estimate \\
\hline 1 & $0.726^{\mathrm{a}}$ & 0.528 & 0.145 & 0.89532 \\
\hline
\end{tabular}

Table 3. Correlation between managers' cognitive skills and staffs' performance

\begin{tabular}{lcc}
\hline Investigated variables & Correlation coefficient & Significant level \\
\hline Managers' cognitive skills and staffs' performance & 0.384 & $0.032 *$ \\
\hline
\end{tabular}

Table 4. Regression coefficient variable of managers' cognitive skills and staffs' performance

\begin{tabular}{ccccc}
\hline Model & $\mathrm{R}$ & R Square & Adjusted R Square & Std. Error of the Estimate \\
\hline 1 & $0.442^{\mathrm{a}}$ & 0.196 & 0.035 & 0.74272 \\
\hline
\end{tabular}

Table 5. Correlation between managers' human skills and staffs' performance

\begin{tabular}{lcc}
\hline Investigated variables & Correlation coefficient & Significant level \\
\hline Managers' human skills and staffs' performance & 0.302 & $0.042^{*}$ \\
\hline
\end{tabular}

Table 6. Regression coefficient variable of managers' human skills and staffs' performance

\begin{tabular}{ccccc}
\hline Model & $\mathrm{R}$ & R Square & Adjusted R Square & Std. Error of the Estimate \\
\hline 1 & $0.308^{\mathrm{a}}$ & 0.094 & 0.024 & 0.83251 \\
\hline
\end{tabular}

Table 7. Correlation between managers' technical skills and staffs' performance

\begin{tabular}{lcc}
\hline Investigated variables & Correlation coefficient & Significant level \\
\hline Managers' technical skills and staffs' performance & 0.432 & $0.002^{*}$ \\
\hline
\end{tabular}

Table 8. Regression coefficient variable of managers' technical skills and staffs' performance

\begin{tabular}{ccccc}
\hline Model & $\mathrm{R}$ & R Square & Adjusted R Square & Std. Error of the Estimate \\
\hline 1 & $0.488^{\mathrm{a}}$ & 0.238 & 0.124 & 0.85371 \\
\hline
\end{tabular}


skills and staffs' performance. As can be seen in Table 4-13, the correlation coefficient between managers' cognitive skills and staffs' performance variable was 0.384 at significance level of $5 \%$. So with $95 \%$ of certainty can claim that there is a significant and direct correlation between managers' cognitive skills and staffs' performance. The regression coefficient between managers' cognitive skills and staffs' performance was 0.442 and its determination coefficient was 0.196. So managers' cognitive skills variable has ability to define $19.6 \%$ of staffs' performance variable changes and/or in other word the regression line only represents $19.6 \%$ of staffs' performance changes.

\section{The second hypothesis}

$\mathrm{H}_{1}$ : there is a direct and significant correlation between managers' cognitive skills and staffs' performance in Red Crescent organization of Fars province.

$\mathrm{H}_{0}$ : there is no direct and significant correlation between managers' cognitive skills and staffs' performance in Red Crescent organization of Fars province.

Pearson correlation coefficient was used in the present study to test the research hypothesis based on correlation between managers' human skills and staffs' performance. As can be seen in Table 4-15, the correlation coefficient between managers' human skills and staffs' performance variable is 0.302 at significance level of $5 \%$. So with $95 \%$ of certainty can claim that there is a significant and direct correlation between managers' human skills and staffs' performance.

The regression coefficient between managers' human skills and staffs' performance was 0.308 and its determination coefficient was 0.094 . So managers' human skills variable has ability to define $9.4 \%$ of staffs' performance variable changes and/or in other word the regression line only represents $4.9 \%$ of staffs' performance changes.

\section{The third hypothesis}

$\mathrm{H}_{1}$ : there is a direct and significant correlation between managers' technical skills and staffs' performance in Red Crescent organization of Fars province.

$\mathrm{H}_{0}$ : there is no direct and significant correlation between managers' technical skills and staffs' performance in Red Crescent organization of Fars province.

Pearson correlation coefficient was used in the present study to test the research hypothesis based on correlation between managers' technical skills and staffs' performance. As can be seen in Table 4-17, the correlation coefficient between managers' technical skills and staffs' performance variable is 0.432 at significance level of $1 \%$. So with $99 \%$ of certainty can claim that there is a significant and direct correlation between managers' technical skills and staffs' performance.

The regression coefficient between managers' technical skills and staffs' performance is 0.488 and its determination coefficient is 0.238 . So managers' technical skills variable has ability to define $23.8 \%$ of staffs' performance variable changes and/or in other word the regression line only represents $23.8 \%$ of staffs' performance changes.

\section{DISCUSSION}

The main hypothesis (there is a direct and significant correlation between managerial triplet skills and staffs' performance in Red Crescent organization in Fars Province) is approved using Pearson correlation test and with $95 \%$ of certainty.

The findings of this research were compared with related researches. Selahshoor (1995) by investigation on affecting factors on efficiency of school management concluded that the factors of planning, organizing, evaluating, personal characteristics of manager, human and social relations, and manager's triplet skills are effective in enhancement of efficiency (18). In order to investigate the importance of each of triplet managerial skills among managers of nursing services, Hosseini (1997) concluded that correct evaluation skill of staffs' performance among technical skills, with the highest chi-square test ratio was the most important skill and the communication skill with co-workers among human relations, and leadership skill among perceptual skills had the highest ratio of chi-square test (19). Asadi. A (1995) in his master's thesis by this title "Role of knowledge and managerial skills of agricultural high school chiefs in educational success of these centers" concluded that dependence of dependent variables of academic achievement and promotion of students' ratio to 
independent variables of managerial knowledge and managerial skills (technical, human, and conceptual) of managers is not at meaningful level of $0.05^{20}$. It was found in the study that was performed by Afshari et al., (2010) by this title "investigation on triplet managerial skills of physical education organizations' managers in universities across Iran" that there is statistically significant difference between triplet managerial skills. The priority of skills in this research includes human, conceptual, and technical skills, respectively. Researches of Bigdeli (2001) and Seyd Shojae (2006) confirm that managers' requirements in triplet managerial skills are technical, conceptual and human skills ${ }^{22,23}$. While, Fertash (2004) stated that educational requirements of business organization managers in Azarbiejan Sharghi Province were cognitive, human and technical skills, respectively ${ }^{21}$.

The first hypothesis (there is a direct and significant correlation between cognitive skills of managers and staffs' performance in Red Crescent in Fars Province) was approved using the Pearson correlation test at $95 \%$ of certainty.

In the study of Naveh Ebrahim and Karimi (2006) that was performed using two questionnaires of performance and training quality showed that there is a positive correlation at level of $5 \%$ between cognitive skills and training quality ${ }^{24}$. In the study of Delkhosh Kasai (2002) that examined the correlation between managerial triplet skills in boys' high school in Tehran and effectiveness of high school concluded that there is a positive correlation between cognitive skills of managers and effectiveness of high schools from perspective of managers and staffs ${ }^{25}$. These findings were nonaligned with researches of Musavian Najaf Abadi (1993) based on lack of correlation ${ }^{26}$.

The second hypothesis (there is a direct and significant correlation between human skills of managers and staff's performance in Red Crescent in Fars Province) was approved using Pearson correlation test at 95\% of certainty.

In the research of Delkhosh Kasmai (2002), that examines the relationships between triplet managerial skills in boys' high schools and effectiveness of high schools found that from the perspective of managers and staffs there is a positive significant correlation between human skill of managers and effectiveness of high schools (25).
The results obtained from Naveh Ebrahim and Karimi (2006) showed that despite significant correlation between technical and conceptual skills in managers of training groups with educational quality of related group not significant correlation observed between human skill and quality of relationship ${ }^{24}$.

The third hypothesis (there is a direct and significant correlation between technical skills of managers and staffs' performance) was approved using Pearson correlation test at $99 \%$ of confidence. Nahid Entesari (2000) in her Master's thesis by this title "investigating of educational requirements in technical, human and conceptual skills and presentation of suitable patterns for training of managers during their work in girls' middle school in Tehran”, Faculty of Psychology of Educational Science, Tehran University; Entesari in her research concluded that the managers of selected schools, for example, had required human and conceptual skills, but did not have required technical skill ${ }^{27}$.

\section{CONCLUSION}

According to the obtained results, existence of human skills was important for the studied managers. Normally, given to the performed researches, the importance of these skills (cognitive, human, and technical) at all managerial levels in hierarchy of management in any organization is considered as an integral part of administrative and managerial duties. And whatever managers have more skills as a result better performance will be seen from staffs.

\section{REFERENCES}

1. Rezaiyan, A, Principles of organization and management, $12^{\text {th }}$ edition, organization of study and development of human sciences of universities (Samt), 2008, Tehran.

2. Iran Nejad Parizi, M., Sasan Gostar, P., Organization and management from theory to practice, $4^{\text {th }}$ edition, institute of Iranian Banking, 2000.

3. http://daneshnameh.roshd.ir, 9/12/2011.

4. Khonifar, H; Poor Hosseini, M, Life skills, $11^{\text {th }}$ edition, Hajar publishing center, 2011.

5. katz, Daniel and Robert L. Kahn (1978); The Social Psychology of Organizations; 2nd ed., 
New York: John Wiley and Sons.

6. P. Rabinz, S, management of organizational behaviors, translated by Omidvaran, S, first edition, Ketab-e Mehrban Nashr Institue, 2005.

7. Rezaiyan. A, management of organizational behaviors (concepts, theories, and applications), $11^{\text {th }}$ edition, Elm and Adab Publication, Tehran, 2007.

8. http://finance-acc. com, 23/4/2012.

9. http://www.hawzah.net, 23/4/2012.

10. Hellreigel, Don and Slocum, John W. Jr. (1989), Management, 5th ed., Addison Wesley Pub. Co.

11. Hersey, Paul and Ken Blanchard (1983 and 1985); Management of Organizational Behavior: Utilizing Human Resources; 4th ed., India: Prentice-Hall.

12. Mehryari, H. A, Tadbir Journal, No. 38, 1998.

13. Rezaiyan, A, Principles of management, $2^{\text {th }}$ edition, organization of study and development of human sciences of universities (Samt), 1991, Tehran.

14. Bovee, Courtland L. and Thill, John V., and wood, Marian Burk and Dovel George P. (1993); Management, International Edition, New York: McGraw-Hill, Inc.

15. Faizi. T, principles of organization and management (all fields of management, accounting, and economy), $8^{\text {th }}$ edition, Payam nor University Publication, 2006, Tehran.

16. Zarei Matin, H, management of human recourses, first edition, Press center Seminary. 2000, Qom.

17. Halachmi, Arie (1999); Mandated Performance Measurement: A help or ahindrance? National Productivity Review, Vol 18, Issue 2, Issn: New York.

18. Selahshor, A. H, investigation of affecting factors on efficiency of school management in terms of mangers and teachers of Isfahan high schools. Master's Thesis, 1995; Shahid Beheshti University, Tehran.

19. Hosseini, $\mathrm{H}$, investigation of managerial skills importance, nursing services managers from viewpoint of nurses in Rasenjan Hospitals, Master's thesis, Kerman University of Medical Sciences.
20. Asadi. A., investigation on role of knowledge and managerial skills of agricultural high school heads in educational success of these centers. Journal of Agricultural Sciences in Iran, 1995; 28 (1): 35-44.

21. Afshari, M., Honari, H., Ghafoori, F., study of managerial triplet skills in managers of department in physical education universities across Iran. Journal of Sport Management., 2010; 2(5): 105-229.

22. Bigdeli, A., Need assessment and presentation of overall frame of middle schools in Khodabande, Iran. Master's thesis, Tehran University, 1991.

23. Sayed Shojae, N. S., Need assessment of Tejart Bank managers in the field of managerial triplet skills to develop their educational programs., Master's thesis, Shahid Beheshti University, 2006.

24. Naveh Ebrahim, A. R., Karimi, V. Study on relations of managements' triplet skills in educational groups with educational quality. Journal of Research and Planning in Higher Education, 2006; 12 (1): 61-78.

25. Delkhosh Kasmai, A, Investigation on relationships of triplet skills (Technical, human, and conceptual) of governmental boy's high schools' managers in Tehran and effectiveness of them in terms of their teachers in years 20012002. Masters' thesis, Tarbiayat Moallem University, Tehran, 2002.

26. Mosavian Najaf Abadi, R., Investigation and comparison of the amount of usage of education and health managers from managerial triplet skills from viewpoint of educational managers and their officials in training hospitals of Isfahan Medical Sciences University, Master's Thesis, Tarbiat Moallem University, Tehran, 1993.

27. Entesari, Nahid., Investigation of training needs in three areas of technical, human, perceptual skills and presentation of suitable pattern for training of managers of girls' middle school in Tehran, Master's thesis, Faculty of Psychology and Educational Science, Tehran University, 2008. 